\title{
Ethnologies
}

Once Upon a Virus: Aids Legends and Vernacular Risk Perception. By Diane Goldstein (Logan, Utah State University Press, 2004. Pp. ix + 177, notes, index, ISBN 0-87421-587-0 paper; 0-87421-586-2 cloth)

\section{Marie Croll}

Volume 28, numéro 1, 2006

Haïti - Face au passé

Haïti - Confronting the Past

URI : https://id.erudit.org/iderudit/014164ar

DOI : https://doi.org/10.7202/014164ar

Aller au sommaire du numéro

Éditeur(s)

Association Canadienne d'Ethnologie et de Folklore

ISSN

1481-5974 (imprimé)

1708-0401 (numérique)

Découvrir la revue

Citer ce compte rendu

Croll, M. (2006). Compte rendu de [Once Upon a Virus: Aids Legends and

Vernacular Risk Perception. By Diane Goldstein (Logan, Utah State University

Press, 2004. Pp. ix + 177, notes, index, ISBN 0-87421-587-0 paper; 0-87421-586-2

cloth)]. Ethnologies, 28(1), 301-304. https://doi.org/10.7202/014164ar d'utilisation que vous pouvez consulter en ligne.

https://apropos.erudit.org/fr/usagers/politique-dutilisation/ 
the unique cultural makeup of Nova Scotia and, in particular, for those working in municipal or federal government.

Valentina Bold

University of Glasgow, Crichton Campus

Dumfries, Scotland

\section{References}

Alexander, Anne. 1997. The Antigonish Movement. Toronto: Thompson Educational Publishing.

Bold, Valentina. 1999. “'Going Out with the Tide': Three Generations of Scotsmen \& the Sea". Northern Scotland.

Caplan, Ronald. 1980. Down North. The Book of Cape Breton's Magazine. Toronto: Doubleday Canada Ltd.

MacKay, Ian. 1994. The Quest of the Folk. Montréal: McGill-Queen's University Press.

Simmel, Georg. 1997. Simmel on Culture. London: Sage.

Once Upon a Virus: Aids Legends and Vernacular Risk Perception. By Diane Goldstein (Logan, Utah State University Press, 2004. Pp. ix + 177, notes, index, ISBN 0-87421-587-0 paper; 0-87421-586-2 cloth)

Folklorist Diane Goldstein dedicates her book to "the people of Conception Bay North and people everywhere who have been stigmatized by illness." This dedication reveals much about her subject matter. Operating from the foundation that "meaning is situated and emergent" (35) she confronts the issue of stigma beginning with its distinct local ramifications. Yet as the dedication also states, Goldstein takes her subject well beyond the local. In a unique collaboration of issues ranging from public health, scientific speculation, risk, and law, she weaves together a cross-cultural perspective on urban legends surrounding HIV/AIDS. Her contention that we "tend not to repeat stories that are lacking in personal and cultural meaning" (35) propels her analysis of these culturally prevalent and significant narratives. Thus she explores the political character of story creation as it pertains to the AIDS epidemic, the ways that AIDS legends enlighten us concerning commonly held views about this disease while simultaneously 
constructing those views and, importantly, the function of these legends as social resistance.

This book is divided into two main parts. Whereas the first part (chapters one to three) places the study in the traditions of disease folklore and narrative as a means of understanding health and risk perception, the second part (chapters four through seven) consists of a series of four case studies that refocus our attention on the local and the vernacular and serves to ground and legitimize the first section through ethnographic research. Their common salient feature is that they all spring from the vernacular and focus on risk perception.

Goldstein's first chapter, "Tag, You've Got Aids”, begins with a story. She explores how the AIDS stigma took root and proliferated in a small Newfoundland community. Her insightful microanalysis examines the wider, more anonymous existence of this disease including underlying issues of public health management and risk perception.

In her second chapter she places HIV/AIDS narratives/rumors/ discourse into the broader genre of contemporary and mass media mediated (i.e., the Internet) legends. Significantly, she points out that health legends, in general, and AIDS legends, in particular, give rise to vernacular expressions of underlying collective concerns about health, vulnerability, trust, and contamination and calls upon us to recognize these legends as sources for social action and personal health decisionmaking.

Third, she directs our focus towards the interrelationship, or lack thereof, between public health education on HIV/AIDS and lay community response. In her view, legends play a substantial role in medical and educational responses to the disease. Yet, correspondingly, public health management fails to reflect much understanding of local concerns. In order for there to be effective public health response, according to Goldstein, there needs to be sound cultural sense, that comes through the use of trained ethnographers and with a recognition that risk perception is "multifaceted and complex," (67) and rooted in individuals and communities.

The author employs narrative, first in a general way, with AIDS origin narratives and what Goldstein calls "the overlapping nature of popular culture and medical culture" (79). The purported origins and transmission of HIV/AIDS (i.e., monkeys or mosquitoes) varies from one narrative to the next and from one medical/scientific report to 
another. Yet, argues Goldstein, the sources from which they spring and the forms in which they present themselves are meaningful; they serve to challenge our taboos, characterize the foreign other, touch on conspiracy theory, and all demonstrate a distrust of Government.

Another case traces the metamorphosis of the "welcome to the world of AIDS" narrative as it adapts to regional idiosyncrasies and understandings. The author moves from there to consider what she refers to as "The Folk Creation and Official Maintenance of a Public Health Scapegoat." Here Goldstein explores the place of legend in official responses to the disease, the relationship between legend and reality, and how these legends come to be enacted.

The final "pinprick" narrative pursues the evolution of one particular HIV/AIDS contamination legend and its many subtle variations with an aim to open up issues surrounding deliberate and anonymous infection. Goldstein links contamination to what she identifies as the increasing sense of alienation at the vernacular level from an increasingly anonymous and invasive medical profession. She further proposes that given such a mounting sense of estrangement "the anonymous AIDS infector might be preferable to the one we know and that public danger is far more desirable than danger in our homes" (140).

In her conclusion, Goldstein brings us back to the beginning which is both her chapter title and her book's title: "Once Upon a Virus". She opened her study with a story and concludes with an emphatic reminder of the importance of storytelling, noting that "the existence of health legends and health narratives should indicate to those who are concerned about public health and who are listening to lay responses that all information requires placement in cultural context. Narratives provide just that" (172).

This insightful and carefully worked study contributes much to our understanding of HIV/AIDS and its interrelationship with both public health and risk perception. In demonstrating how narrative creates the forms of our interactions with HIV/AIDS in particular and disease in general, Goldstein has provided a valuable insight that has far-reaching implications for research and practice alike. While throughout this book she defines repeatedly (and somewhat aggravatingly) her intentions for writing this study, on the whole Goldstein writes clearly and sensitively. She successfully weaves together many analytical threads. Because Goldstein also painstakingly defines a great many of the disciplinary terms that she employs in Once Upon a Virus it is potentially also a very 
teachable work of value in a variety of disciplines and accessible even to the uninitiated in the fields of AIDS research, social policy, Newfoundland studies and Cultural Studies. Overall, Once Upon a Virus is a fine work of ethnographic research that in fact champions ethnography both by example and in its call for an ethnographic approach to understanding legend making.

Marie Croll

Sir Wilfred Grenfell College

Corner Brook, Newfoundland and Labrador

Enduring Hardship: The Chinese Laundry in Canada. By Ban Seng Hoe. Mercury Series, Cultural Studies Paper 76 (Gatineau: Canadian Museum of Civilization, 2003. Pp. 86, ISBN 0660190788).

If you read the Canadian Encyclopedia's entry on Chinese immigrants, you would learn nothing of the laundry business' importance for the Chinese in Canada in the first half of the twentieth century. Enduring Hardship aims to fill this gap. Produced as a companion to the Canadian Museum of Civilization's permanent exhibition of the same title, this brief social and oral history of Chinese laundry workers in Canada contributes to the growing literature on the history of ethnic groups in Canada.

Enduring Hardship argues that Chinese immigrant men created laundry work as their niche in Canada's racist economy because systematic discrimination gave them few options. The book focuses on the people — the laundrymen and their families — and, through interviews and photographs, lets them talk about the arduous work of manually cleaning other people's soiled clothes and dirty linen.

Chinese men and a few women, mostly from California and China's Guangdong and Fujian provinces, came to British Columbia in the wake of the gold rushes of the 1850s and the building of the railways in the 1880s. By the end of the nineteenth century, some ChineseCanadians began to settle in other provinces, where, the further east they went, the more likely they were to establish themselves in the laundry business. This was particularly true for Central Canada. Quebec's Chinese population was 2,750 in 1931, and there were 1,272 Chinese laundries. In the same year, Ontario counted 6,919 Chinese and 2,508 